\title{
When moult overlaps migration: moult-related changes in plasma biochemistry of migrating common snipe
}

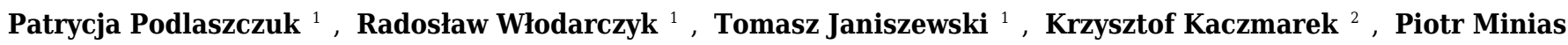 \\ Corresp. 1 \\ ${ }^{1}$ Department of Biodiversity Studies and Bioeducation, University of Łódź, Łódź, Poland \\ 2 Department of Electrocardiology, Medical University of Łódź, Łódź, Poland \\ Corresponding Author: Piotr Minias \\ Email address: pminias@biol.uni.lodz.pl
}

Moult of feathers entails considerable physiological and energetic costs to an avian organism. Even under favourable feeding conditions, endogenous body stores and energy reserves of moulting birds are usually severely depleted. Thus, most species of birds separate moult from other energy-demanding activities, such as migration or reproduction. Common snipe Gallinago gallinago is an exception, as during the first autumn migration many young snipe initiate the post-juvenile moult, which includes replacement of body feathers, lesser and median wing coverts, tertials and rectrices. Here, we evaluated moultrelated changes in blood plasma biochemistry of the common snipe during a period of serious trade-off in energy allocation between moult and migration. For this purpose, concentrations of basic metabolites in plasma were evaluated in more than 500 young snipe migrating through Central Europe. We found significant changes in the plasma concentrations of total protein, triglyceride and glucose over the course of moult, while the concentrations of uric acid and albumin did not change. Total protein concentration increased significantly in the initial stage of moult, probably as a result of increased production of keratin, but it decreased to the pre-moult level at the advanced stage of moult. Plasma triglyceride concentration decreased during the period of tertial and rectrice moult, which reflected depletion of endogenous fat reserves. By contrast, glucose concentration increased steadily during the course of moult, which could be caused by increased catabolism of triglycerides (via gluconeogenesis) or, alternatively, due to increased glucocorticoids as a stress response. Our results suggest that physiological changes associated with moult may be considered important determinants of the low pace of migration typical of the common snipe. 
1 When moult overlaps migration: moult-related changes in plasma biochemistry

2 of migrating common snipe

3

4 Patrycja Podlaszczuk ${ }^{1}$, Radosław Włodarczyk ${ }^{1}$, Tomasz Janiszewski ${ }^{1}$, Krzysztof Kaczmarek $^{2}$, Piotr

5 Minias $^{1 *}$

6

$7{ }^{1}$ Department of Biodiversity Studies and Bioeducation, University of Łódź, Banacha 1/3, 90-237

8 Łódź, Poland

$9 \quad{ }^{2}$ Medical University of Łódź, Sterlinga 1/3, 91-425 Łódź, Poland

10

11 Corresponding author:

12 Piotr Minias, pminias@op.pl 


\section{ABSTRACT}

14 Moult of feathers entails considerable physiological and energetic costs to an avian organism. Even under favourable feeding conditions, endogenous body stores and energy reserves of moulting birds are usually severely depleted. Thus, most species of birds separate moult from other energy-demanding activities, such as migration or reproduction. Common snipe Gallinago gallinago is an exception, as during the first autumn migration many young snipe initiate the post-juvenile moult, which includes replacement of body feathers, lesser and median wing coverts, tertials and rectrices. Here, we evaluated moult-related changes in blood plasma biochemistry of the common snipe during a period of serious trade-off in energy allocation between moult and migration. For this purpose, concentrations of basic metabolites in plasma were evaluated in more than 500 young snipe migrating through Central Europe. We found significant changes in the plasma concentrations of total protein, triglyceride and glucose over the course of moult, while the concentrations of uric acid and albumin did not change. Total protein concentration increased significantly in the initial stage of moult, probably as a result of increased production of keratin, but it decreased to the pre-moult level at the advanced stage of moult. Plasma triglyceride concentration decreased during the period of tertial and rectrice moult, which reflected depletion of endogenous fat reserves. By contrast, glucose concentration increased steadily during the course of moult, which could be caused by increased catabolism of triglycerides (via gluconeogenesis) or, alternatively, due to increased glucocorticoids as a stress response. Our results suggest that physiological changes associated with moult may be considered important determinants of the low pace of migration typical of the common snipe. 


\section{INTRODUCTION}

34 Moulting is a process by which the birds maintain feathers in good quality, which improves birds' flight

performance and enhances thermoregulation. However, synthesis of feathers is one of the most

physiologically costly events in the annual cycle of birds and it requires substantial stores of nutrients in body (Murphy, 1996). While the apparent nutrient and energy costs of moult associated with deposition of materials in new feathers may be relatively mild when compared with the costs of maintenance or reproduction (Murphy \& King, 1992), the process of moult requires a wide spectrum of metabolic adjustments that are not directly related to plumage synthesis. These additional metabolic processes include recrudescence of the integument, cyclic osteoporosis, and an increased whole-body protein turnover, which may add up to daily energy costs of peak moult exceeding $50 \%$ of basal metabolic rate (Murphy \& King, 1992). In fact, the energy deposited daily as keratins in feather was estimated to equal only ca. $10 \%$ of the energy costs of moult and much higher energy costs were associated with protein metabolism not directly related to keratin synthesis (Murphy \& Taruscio, 1995).

The biochemical analysis of blood is a technique widely used to indicate avian body condition and to investigate physiological processes during different phases of life. In general, plasma metabolites reflect various aspects of physiological condition and characterize the feeding state of birds. Total protein and triglyceride levels reliably indicate nutrient status of wild and captive birds (Jenni-Eiermann \& Jenni, 1998; Jenni-Eiermann, Jenni \& Piersma, 2002; Albano et al., 2016), although triglyceride levels may also vary in relation to environmental conditions and stress (Artacho et al., 2007; Ibañez et al., 2015). Glucose level in plasma decreases during periods of fast and, thus, may serve as an indicator of short-term changes in food intake (Jenni-Eiermann \& Jenni, 1998; Totzke et al., 1999; Alonso-Alvarez et al., 2002). Numerous studies indicated that glucose levels are positively correlated with different components of condition or with a broadly-defined individual quality (Alonso-Alvarez et al., 2002; Minias \& Kaczmarek, 2013). High levels of plasma glucose are also associated with increased glucocorticoids as 
57 a stress response (Mondal et al., 2011), although this relationship may be obscured by the processes of

58 protein catabolism, gluconeogenesis, and insulin regulation (Remage-Healey \& Romero, 2001; Cyr et al.,

59

60

61

62

63

64

65

66

67 2007). Plasma concentrations of nitrogenous excretion components, such as uric acid, increases substantially in response to starvation, when tissue proteins are actively mobilized as a source of energy. Plasma concentration of uric acid is a good indicator of condition, especially when individuals have low fat reserves, which rapidly activates protein catabolism during food shortage (Villegas et al., 2002). Finally, low albumin concentration may reflect acute diseases and chronic infection or inflammation, which may result from decreased allocation of resources to the immune function (Hõrak et al., 2002). The presented literature shows that changes in blood plasma biochemistry may well serve to evaluate physiological costs of moult. Earlier studies investigated changes in plasma biochemistry during moult in captive birds (Dolnik \& Gavrilov, 1979; Murphy \& King, 1984) and other wild-living but flightless birds (Ghebremeskel et al., 1989; Cherel, Charrassin \& Challet, 1994). However, few, if any, papers have examined moult-related changes in plasma biochemistry of wild birds during migration. Most avian species separate moult from other energy-demanding activities, such as migration or reproduction, but several species of birds have been reported to show a moult-migration overlap to a varying degree (Pérez-Tris et al., 2001; Rohwer et al., 2009), including the common snipe Gallinago gallinago (Podlaszczuk et al., 2016). Adult common snipe start post-breeding moult at the breeding grounds, as soon as they conclude reproductive activities, and continue moulting during migration. Young common snipe typically begin the partial post-juvenile moult during their first autumn migration, although probably some individuals can delay moulting until arrival at wintering grounds (Podlaszczuk et al., 2016). The post-juvenile moult of the common snipe is more extensive and, thus, more energetically expensive than in other waders, as it includes replacement of body feathers, lesser and median wing coverts, tertials, and rectrices (Włodarczyk et al., 2008; Minias et al., 2010a). In these respects, the common snipe provide a good opportunity to study moult-related changes in blood plasma biochemistry 
81 during a period of serious trade-off in energy allocation between migration and moult. The aim of this

82 study was to determine physiological consequences of moult in migrating common snipe. For this

83 purpose, we measured plasma concentrations of basic metabolites in over half a thousand moulting and non-moulting young common snipe at their final phase of migration through Central Europe.

\section{METHODS}

\section{Study site and species}

Common snipe were captured at the Jeziorsko reservoir $\left(51^{\circ} 40^{\prime} \mathrm{N}, 18^{\circ} 40^{\prime} \mathrm{E}\right)$, central Poland, during the autumn migration (04 August - 25 September) to the south-west. Jeziorsko reservoir is one of the most important stopover sites for migrating waders and waterfowl in inland Poland, due to the water management policies which ensure considerable seasonal oscillations of water level. In autumn, water level at the reservoir decreases at a constant rate, continuously exposing new areas of mudflats, which provide abundant food resources and attract large flocks of migrating waders. The maximum number of common snipe at the site exceeds a thousand individuals in August (Janiszewski et al., 1998). migrates to the wintering grounds in South-Western Europe (Cramp \& Simmons, 1986). As indicated by ringing recoveries, common snipe migrating through inland Poland originate mostly from Central Russian populations (Fig. 1; Minias et al., 2010b). Although common snipe also breed in Poland and neighbouring Central European countries, there is no evidence that local individuals use Jeziorsko reservoir as a fuelling site prior to autumn migration, as they probably start their migration before the suitable feeding habitats (mudflats) start to appear at the reservoir (usually in early or mid-August). While the common snipe is known to migrate according to the strategy of energy minimization, which is 
104 reservoir is likely to be one of the last staging sites for birds wintering in France and other West-

105 European countries.

106

107

\section{General field procedures}

108

109

110

111

112

113

114

115

116

117

118

119

120

121

122

123

124

125

126

127

In total, we caught 1007 first-year common snipe during seven migration seasons (2009-2015). Snipe were captured in walk-in traps and mist nets, occasionally with vocal stimulation. All birds were ringed and aged according to plumage (Kaczmarek et al., 2007; Włodarczyk et al., 2008). The sex of birds was determined either molecularly (in 2009) from blood samples, following protocols developed by Kahn, John \& Quinn (1998), or by morphological measurements, using discriminant equations developed for the same migratory population of the common snipe (Włodarczyk et al., 2011). For sexing by morphology, bill length and distance between the tips of two outermost rectrices were measured with calipers $( \pm 0.1 \mathrm{~mm})$ and the vane length of the outermost rectrix was measured with a ruler $( \pm 1 \mathrm{~mm})$. Fieldwork was performed with permission from the Regional Environmental Protection Directorate in Łódź, Poland. Catching, ringing, and handling birds was performed with permission from the Polish Academy of Sciences, with the approval of the Ministry of Environment in Poland and General Environmental Protection Directorate in Poland.

\section{Recording moult}

In all captured snipe we quantified the stage of post-juvenile moult. During post-juvenile moult snipe change their natal feathers (body feathers, lesser and median wing coverts, tertials, and rectrices) to an adult-type plumage (Fig. 2). Thus, when post-juvenile moult is complete, first-year birds become indistinguishable from adults based on the plumage characteristics. However, few young birds (if any) finish their post-juvenile moult before they reach wintering grounds. Throughout the seven years of study we captured only 43 individuals in fresh (recently moulted) adult-type plumage, most of which 
128 were probably adults. All these birds were excluded from analyses. The remaining young birds were

129 classified into one of three moult categories: 1) pre-moult (no feathers moulted); 2) initial stage of moult

130 (only body feathers and wing coverts in active moult); 3) advanced stage of moult (tertials or rectrices in

131 active moult). Moult progress was also quantified in more detail for birds that moulted tertials or

132 rectrices. For this purpose, each tertial $(n=8)$ and rectrix $(n=14)$ was given a moult score according to

133 the feather scoring system developed by Ashmole (1962), where: 0 - old feather, 1 - old feather missing

134 or a new feather in a pin, 2 - new feather up to one third grown, 3 - new feather between one and two

135 thirds grown, 4 - new feather more than two thirds grown, 5 - new feather fully developed. A sum of all

136 moult scores for individual feathers was used as a general moult score (max. 110, when all tertials and

137 rectrices were renewed).

138

\section{Plasma biochemistry}

140 About $50 \%$ of captured young snipe ( $n=538$ individuals) were selected for plasma biochemistry

141

measurements. Between 20 and $40 \mu$ of blood was collected from the ulnar vein of each bird into

heparinized capillary tubes. Blood sampling was performed with permission from the Local Bioethical

Commission in Łódź, Poland. Samples were centrifuged at 6000 rpm for 5 min within an hour of

collection to separate plasma from blood cells, and kept at $-20^{\circ} \mathrm{C}$ until analysis. Plasma metabolite

concentrations (total protein, albumin, triglycerides, glucose, and uric acid) were analysed with a

spectrophotometer (BTS-330, BioSystems Reagents \& Instruments, Barcelona, Spain) using commercial

kits of the same manufacturer (BioSystems Reagents \& Instruments, Barcelona, Spain). All analyses were

conducted according to the manufacturer protocols using the following methods: total protein (biuret

reaction), albumin (bromocresol green), triglycerides (glycerol phosphate oxidase/peroxidase), glucose

151 measured in a flow cuvette against a blank reagent at the following wave lengths: $500 \mathrm{~nm}$ (glucose, 
152 triglycerids), $520 \mathrm{~nm}$ (uric acid), $545 \mathrm{~nm}$ (total protein), and $630 \mathrm{~nm}$ (albumin). Run-to-run repeatability

153 (R) and linearity limits (LL) were specified as follows: total protein (R: 1.85\%; LL: $150 \mathrm{~g} / \mathrm{L}$ ), albumin (R:

154 1.90\%; LL: $70 \mathrm{~g} / \mathrm{L}$ ), triglycerides (R: 2.15\%; LL: $600 \mathrm{mg} / \mathrm{dL}$ ), glucose (R: 2.3\%; LL: $500 \mathrm{mg} / \mathrm{dL}$ ), and uric acid

155 (R: $2.00 \%$, LL: $25 \mathrm{mg} / \mathrm{dL}$ ). The applied biochemical methods followed the standard methodology used in

156 avian studies (e.g. Artacho et al., 2007). Since the amount of plasma collected from each birds was often

157 not sufficient to measure all five plasma biochemistry parameters, sample sizes for each parameter are

158 different (Table 1). Distributions of all plasma metabolite concentrations were reasonably close to

159 normal (skewness: $0.08-0.69)$ and thus were not transformed.

160

\section{Statistical analyses}

162 Differences in plasma biochemistry parameters between consecutive stages of post-juvenile moult were 163 analysed with general linear models (GLMs), separately for each parameter. In each model, we 164 controlled for the effects of sex, year, date of capture (Julian day), and hour of capture. Date was

165 standardized to equal unit variances within each season $\left(z=\frac{x-\mu}{\sigma}\right.$, where $\mu$ is the mean date of capture

166 in a given season and $\sigma$ is the standard deviation of capture date in a given season) to account for 167 annual variation in the timing of migration. For birds at the advanced stage of moult, we also used GLMs 168 to investigate the effect of moult score on plasma metabolite concentrations. In these models, the 169 general moult score calculated for tertials and rectrices was entered as a covariate. To obtain more 170 parsimonious reduced models, we removed non-significant $(p>0.15)$ predictors from initial full models.

171 All statistical analyses were performed with Statistica 10.0 (StatSoft, Tulsa, OK, USA). All values are 172 presented as means $\pm \mathrm{SE}$.

\section{RESULTS}


$17543.7 \%$ of young common snipe showed signs of post-juvenile moult $(n=538)$. Most moulting snipe

$176(74.9 \%, n=235)$ were at the initial stage of moult, while the remaining $25.1 \%$ were at the advanced

177 stage of moult.

Plasma concentrations of total protein and glucose differed significantly between the consecutive stages of post-juvenile moult (Table 2,3$)$. Total protein concentration was significantly higher at the initial stage of moult $(35.57 \pm 0.52 \mathrm{~g} / \mathrm{l})$ when compared to the pre-moult stage (33.33 \pm $p=0.011)$. There was no significant difference in the total protein concentration between the pre-moult and advanced-moult stages (Tukey test: $p=0.67$; Fig. 3a). By contrast, glucose concentration was higher at the advanced stage of moult than during the pre-moult stage $(511.6 \pm 20.6 \mathrm{mg} / \mathrm{dl}$ vs. $454.8 \pm 7.1$ $\mathrm{mg} / \mathrm{dl}$; ; Tukey test: $\mathrm{p}=0.039$; Fig. $3 \mathrm{~b})$. Snipe at the initial stage of moult had an intermediate concentration of glucose (Fig. 3b). Other plasma parameters showed no variation with the moult stage

187 (Table 4). Only triglyceride concentration in plasma changed with the moult score of snipe that moulted tertials or rectrices $\left(F_{1,61}=4.10, p=0.047\right)$, and it significantly decreased during moult of tertials and rectrices ( $\beta=-0.29 \pm 0.14 ;$ Fig. 4). The other plasma parameters (total protein, albumin, glucose, and uric acid concentrations) showed no variation related to the moult score of tertials and rectrices (all $p>$ 0.05).

\section{DISCUSSION}

Concentrations of total protein, triglycerides and glucose in plasma changed significantly during the post-juvenile moult of the common snipe. At least some of these changes in blood plasma biochemistry are likely associated with the use of energy and nutrients during plumage synthesis or during other moult-related metabolic processes, which greatly contribute to the overall costs of moult (e.g. 
later during the advanced stage of feather replacement, returning to the low pre-moult level. Snipe have

probably the highest protein demand at the beginning of moult, due to the rapid acceleration of keratin

synthesis for feather production and other metabolic processes associated with early phases of moult,

such as vascularization of the active feather follicles, pulp formation, and an increase of erythrocytes

(deGraw \& Kern, 1985; Murphy \& King,1992). It has been shown that deposition of protein as keratins of

feathers may equal a quarter or more of the total protein mass of the bird (Newton, 1968; Murphy \&

Taruscio, 1995; Roman et al., 2009). Production of keratin depends largely upon sulphur containing

amino acids (cysteine and cystine), which, thus, may be critical for plumage synthesis. For example,

require large amounts of glutathione, which primarily consists of sulphur containing amino acids.

However, besides playing a role in feather synthesis, plasma proteins have a variety of immunological

and transport functions and are important indicators of nutritional state and health of a bird (Jenni-

Eiermann \& Jenni, 1996). Plasma proteins also carry a range of metabolites (Jenni-Eiermann \& Jenni,

1996). Reduction of total protein content is an indicator of many pathological changes (malnutrition), as

proteins contribute to a pool of amino-acids for protein synthesis and can act as a source of energy

(Jenni-Eiermann \& Jenni, 1996).

Our findings are similar to those of Dolnik \& Gavrilov (1979) who found that total protein level

increased at the initial stage of moulting in the chaffinch Fringilla coelebs, which was due to intensive 
223 Nevertheless, Ghebremeskel et al. (1989) found total plasma protein to be significantly lower in the

224 post-moult than the pre-moult stage in rockhopper Eudyptes crestatus and Magellanic penguins

225 Spheniscus magellanicus. Species vary in their baseline protein level and this may result from variations

226 in the supply of amino acids and energy. Most species rely mostly on their diet to meet the growing

227 demand for protein during moulting, but some birds, such as penguins, which do not feed during moult,

228 use endogenous nutrients to synthesize feathers (Cherel, Charrassin \& Challet, 1994). While it remains

229 unknown whether the common snipe primarily use endogenous or exogenous nutrients for feather

230 synthesis, it was found that snipe depend on endogenous energy from adipocyte cells during moult

231 period (Minias et al., 2010a). The decreased levels of plasma total protein observed during the final

232 stages of moult result from an ongoing protein accumulation in feathers or muscles, as well as from less

233 intensive synthesis in the liver (Roman et al., 2009). At the advanced stage of moult, some proteins

234 obtained with food could be also catabolized into amino acids and keto acids, and then used primarily as

235 energy or for synthesis of fatty acids (Artacho et al., 2007).

Plasma triglycerides are a well-known indicator of malnutrition or fasting, and their

concentration decreases rapidly even during overnight fasting (e.g. Jenni-Eiermann \& Jenni, 1996; Jenni

\& Schwilch, 2001; Jenni-Eiermann, Jenni \& Piersma, 2002). We found that plasma triglyceride levels

decreased in moulting common snipe, which is consistent with previous findings that fat reserves of

snipe decreased by ca. $50 \%$ between the initial and final stages of the post-juvenile moult (Minias et al.,

2010a). The decreasing plasma triglyceride level observed during moult is probably an indicator of

increasing problems with food supply. To satisfy high energy demand, snipe rely on their fat reserves

(Minias et al., 2010a) and probably on catabolised protein obtained from dietary sources. Birds

catabolise fat reserves to compensate for energy deficiencies in food intake, which is especially likely 
247 showed that the level of metabolized energy increases during the initial stages of moult, but decreases

248 in the next phases of moult and finally settle at a level below initial values upon moult completion

249 (Newton, 1968; Myrcha \& Pinowski, 1970; Dolnik \& Gavrilov, 1979; Jenni-Eiermann \& Jenni, 1996;

250 Artacho et al., 2007).

251 In contrast to triglycerides, plasma glucose concentration in the common snipe steadily

252 increased from the start of the moult until its advanced stage. Glucose is the main product of the

253 carbohydrate metabolism and it is obtained from the diet. Some studies indicate that good body

254 condition is associated with increased glucose level (Minias \& Kaczmarek, 2013). A decrease in glucose

255 level in birds could be an indicator of short fasting periods (Jenni-Eiermann \& Jenni, 1994, 1997),

256 however, in some species plasma glucose concentration negatively correlated with body mass (Kaliński

257 et al., 2014). During starvation, glucose is produced from stored glycerol and amino acids or by

258 gluconeogenesis (Herzberg et al., 1988) and may also occur as a stress-induced hyperglycaemia with

259 increased glucocorticoids (Remage-Healey \& Romero, 2001).

There are two likely explanations for the increasing levels of plasma glucose during moult in the

261

262

263

264

265

266

267

268

269

270

common snipe. First, snipe use their fat reserves during moult (Minias et al., 2010a), which is supported by decreasing plasma triglyceride concentrations and, thus, the increasing glucose level may be an effect of the catabolism of triglycerides, stored in adipocyte cells. During lipolysis, the triglycerides are split into monoacylglycerol units which are converted to free fatty acids and glycerol. Glycerol can be then metabolised into glucose by conversion into dihydroxyacetone phosphate and then into glyceraldehyde 3-phosphate in the process of gluconeogenesis (Herzberg et al., 1988). Consequently, we cannot exclude that increasing catabolism of fat may simultaneously elevate plasma glucose levels during moult.

The second reason for increasing plasma glucose concentration may be associated with elevated levels of corticosteroids. Glucocorticoids increase glucose level by working as an insulin antagonist and stimulating lipolysis in adipose tissue, which results in an increase in plasma free fatty acids and glycerol 
271 levels (Remage-Healey \& Romero, 2001; Ramenofsky, 2011). Several studies have shown that

272 glucocorticoid activity is associated with migration (Landys, Ramenofsky \& Wingfield, 2006; Ramenofsky,

273 2011) and high levels of plasma corticosterone have been well documented in many long-distance

274 migrants (Falsone, Jenni-Eiermann \& Jenni, 2009; Landys-Ciannelli et al., 2002; Reneerkens et al., 2002).

275 Thus, it seems likely that migrating young common snipe may show higher levels of corticosterone

276 required for the maintenance of migratory condition (Ramenofsky, Piersna \& Jukema, 1995; Holberton,

277 1999; Landys-Ciannelli et al., 2002; Reneerkens et al., 2002; Falsone, Jenni-Eiermann \& Jenni, 2009). On

278 the other hand, there is no agreement on how corticosterone level is affected by moult. While baseline

279 and stress-induced levels of corticosterone were lower during moult in the common starlings Sturnus

280 vulgaris (Romero \& Remage-Healey, 2000), some other studies suggested that corticosterone

281 suppression is not a prerequisite for synthesis of high-quality feathers (Buttemer, Addison \& Astheimer,

282 2015). Regardless of the mechanism responsible for plasma glucose regulation in moulting common

283 snipe, both pre-moult and moult levels of plasma glucose in snipe were very high when compared to

284 glycemic levels in other bird species (Prinzinger \& Misovic, 1994; Beuchat \& Chong, 1998). This suggests

285 that plasma glucose concentration in moulting snipe was above the threshold of glycemic requirement

286 and may not be indicative of catabolic compromise.

In conclusion, our study indicates significant changes in blood plasma biochemistry during the

post-juvenile moult in the common snipe. These changes, which indicate high nutritional and

physiological costs of moult, might be among the primary determinants for the low pace of migration in

this species. The common snipe minimizes energy expenditure during autumn migration, a strategy

characterized by low refuelling rates, accumulation of small fat reserves, and migrating by short 
294 moult and migration may prevent the common snipe from adopting migration strategy of energetically-

295

296

297

298

299

300

301

302

303

304

305

306

307

308

309

310

311

312

313

314

315

316

317

318

319

320

321

322

323

324

expensive long-distance migratory flights.

\section{ACKNOWLEDGEMENTS}

We would like to thank all participants of fieldwork at Jeziorsko reservoir, especially Tomasz Iciek, Anna Piasecka, and Przemysław Wylegała. We also thank Magdalena Remisiewicz and an anonymous reviewer for constructive comments on the earlier drafts of the manuscript.

\section{Data Deposition}

The raw data have been supplied as a Supplemental Dataset.

\section{REFERENCES}

Albano N, Santiago-Quesada F, Villegas A, Sánchez-Guzmán JM, Masero JA. 2016. Plasma metabolites correlate with weekly body mass changes in migrating black-tailed Godwits Limosa limosa feeding on different diets. Journal of Ornithology 157(1):201-207.

Alonso-Alvarez C, Veland A, Ferrer M, Veir JA. 2002. Changes in plasma biochemistry and body mass during incubation in the yellow-legged gull. Waterbirds 25(2):253-258.

Artacho P, Soto-Gamboa M, Verdugo C, Nespolo RF. 2007. Blood biochemistry reveals malnutrition in Black-necked Swans (Cygnus melanocoryphus) living in a conservation priority area. Comparative Biochemistry and Physiology A 146(2):283-290.

Ashmole NP. 1962. The black noddy Anous tenuirostris on Ascension Island Part 1. General Biology. Ibis 103(2):235-273.

Beuchat CA, Chong C. 1998. Hyperglycemia in hummingbirds and its consequences for hemoglobin glycation. Comparative Biochemistry and Physiology A 120(3):409-416.

Buttemer WA, Addison BA, Astheimer LB. 2015. Lack of seasonal and moult-related stress modulation in an opportunistically breeding bird: the white-plumed honeyeater (Lichenostomus penicillatus). Hormones and Behavior 76:34-40.

Cherel Y, Charrassin JB, Challet E. 1994. Energy and protein requirements for molt in the king penguin Aptenodytes patagonicus. American Journal of Physiology 266(4):R1182-R1188.

Cramp S, Simmons KEL. (eds). 1986. The birds of the Western Palearctic. Vol. 3. Oxford University Press, Oxford. 
Cyr NE, Earle K, Tam C, Romero LM. 2007. The effect of chronic psychological stress on corticosterone, plasma metabolites, and immune responsiveness in European starlings. General and Comparative Endocrinology 154:59-66.

deGraw WA, Kern MD. 1985. Changes in the blood and plasma volume of Harris' sparrows during postnuptial molt. Comparative Biochemistry and Physiology A 81(4):889-893.

Dolnik VR, Gavrilov VM. 1979. Bioenergetics of molt in the chaffinch (Fringilla coelebs). Auk 96(2):253-264.

Driver EA. 1981. Hematological and blood chemical values of mallard, Anas p. platyrhynchos, drakes before, during and after remige moult. Journal of Wildlife Diseases 17(3):413-421.

Falsone K, Jenni-Eiermann S, Jenni L. 2009. Corticosterone in migrating songbirds during endurance flight. Hormones and Behavior, 56(5):548-556.

Ghebremeskel K, Williams G, Keymer IF, Horsley D, Gardner DA. 1989. Plasma chemistry of rockhopper (Eudyptes crestatus), Magellanic (Spheniscus magellanicus) and gentoo (Pygoscelis papua) wild penguins in relation to moult. Comparative Biochemistry and Physiology A 92(1):43-47.

Herzberg GR, Brosnan JT, Hall B, Rogerson M. 1988. Gluconeogenesis in liver and kidney of common murre (Uria aalge). American Journal of Physiology 254(6):R903-R907.

Holberton RL. 1999. Changes in patterns of corticosterone secretion concurrent with migratory fattening in a Neotropical migratory bird. General and Comparative Endocrinology 116(1):49-58.

Hõrak P, Saks L, Ots I, Kollist H. 2002. Repeatability of condition indices in captive Greenfinches (Carduelis chloris). Canadian Journal of Zoology 80(4):636-643.

Ibañez AE, Najle R, Larsen K, Montalti D. 2015. Hematology, Biochemistry and Serum Protein Analyses of Antarctic and non-Antarctic Skuas. Waterbirds 38(2):153-161.

Janiszewski T, Włodarczyk R, Bargiel R, Grzybek J, Kaliński A, Lesner B, Mielczarek S. 1998. Birds of the Jeziorsko reservoir in 1986-1996. Notatki Ornitologiczne 39(3):121-150 (in Polish with English summary).

Jenni L, Schwilch R. 2001. Plasma metabolite levels indicate change in body mass in reed warblers Acrocephalus scirpaceus. Avian Science 1(1):55-65.

Jenni-Eiermann S, Jenni L. 1994. Plasma metabolite levels predict individual body-mass changes in a small long-distance migrant, the Garden Warbler. Auk 111(4):888-899.

Jenni-Eiermann S, Jenni L. 1996. Metabolic differences between the postbreeding, moulting and migratory periods in feeding and fasting passerine birds. Functional Ecology (10)1:62-72.

Jenni-Eiermann S, Jenni L. 1997. Diurnal variation of metabolic responses to short-term fasting in passerine birds during the postbreeding, molting and migratory period. Condor 99(1):113-122.

Jenni-Eiermann S, Jenni L. 1998. What can plasma metabolites tell us about the metabolism, physiological state and condition of individual birds? An overview. Biologia e Conservazione della Fauna 102:312-319.

Jenni-Eiermann S, Jenni L, Piersma T. 2002. Plasma metabolites reflect seasonally changing metabolic processes in a long-distance migrant shorebird (Calidris canutus). Zoology 105(3):239-246.

Kaczmarek K, Minias P, Włodarczyk R, Janiszewski T, Kleszcz A. 2007. New insight in ageing of Common Snipe Gallinago gallinago - a value of wing-coverts contrast. Ringing and Migration 23:223-227.

Kahn NW, John JS, Quinn TW. 1998. Chromosome-specific intron size differences in the avian CHD gene provide an efficient method for sex identification in birds. Auk 115(4):1074-1078. 
Kaliński A, Bańbura M, Glądalski M, Markowski M, Skwarska J, Wawrzyniak J, Zieliński P, Cyżewska I, Bańbura J. 2014. Landscape patterns of variation in blood glucose concentration of nestling blue tits (Cyanistes caeruleus). Landscape Ecology 29(9):1521-1530.

Klasing KC. 1998. Metabolism and storage of triglycerides. In: Klasing KC, ed. Comparative Avian Nutrition. CAB Intl, New York, 182-194.

Landys MM, Ramenofsky M, Wingfield JC. 2006. Actions of glucocorticoids at a seasonal baseline as compared to stress-related levels in the regulation of periodic life processes. General and Comparative Endocrinology 148(2):132-149.

Landys-Ciannelli MM, Ramenofsky M, Piersma T, Jukema J, Wingfield JC. 2002. Baseline and stress-induced plasma corticosterone during long-distance migration in the bar-tailed godwit, Limosa lapponica. Physiological and Biochemical Zoology 75(1):101-110.

Minias P, Kaczmarek K. 2013. Concentrations of plasma metabolites as predictors of nestling condition in the Great Cormorant (Phalacrocorax carbo sinensis). Ornis Fennica 90(3):142-150.

Minias P, Kaczmarek K, Włodarczyk R, Janiszewski T. 2010a. Adjustments and exploitation of body stores during post-juvenile molt in Common Snipe Gallinago gallinago. Waterbirds 33(1):116-120.

Minias P, Włodarczyk R, Meissner W, Remisiewicz M, Kaczmarek K, Czapulak A, Chylarecki P, Wojciechowski A, Janiszewski T. 2010b. The migration system of Common Snipe Gallinago gallinago on autumn passage through Central Europe. Ardea 98(1):13-19.

Mondal DK, Chattopadhyay S, Batabyal S, Bera AK, Bhattacharya D. 2011. Plasma biochemical indices at various stages of infection with a field isolate of Eimeria tenella in broiler chicken. Veterinary World 4(9):404-409.

Murphy ME. 1996. Energetics and nutrition of molt. In: Carey C, ed. Avian energetics and nutritional ecology. Springer US, 158-198.

Murphy ME, King JR. 1984. Sulfur amino acid nutrition during molt in the white-crowned sparrow. 1. Does dietary sulfur amino acid concentration affect the energetics of molt as assayed by metabolized energy? Condor 86(3):314-323.

Murphy ME, King JR. 1992. Energy and nutrient use during moult by White-crowned Sparrows Zonotrichia leucophrys gambelii. Ornis Scandinavica 23(3):304--313.

Murphy ME, Taruscio TG. 1995. Sparrows increase their rates of tissue and whole-body protein synthesis during the annual molt. Comparative Biochemistry and Physiology A 111(3):385-396.

Myrcha A, Pinowski J. 1970. Weights, body composition, and caloric value of postjuvenal molting European Tree Sparrows (Passer montanus). Condor 72(2):175-181.

Newton I. 1968. The temperatures, weights, and body composition of molting Bullfinches. Condor 70(4):323-332.

Pérez-Tris J, de la Puente J, Pinilla J, Bermejo A. 2001. Body moult and autumn migration in the barn swallow Hirundo rustica: is there a cost of moulting late. Annales Zoologici Fennici 38:139-148.

Podlaszczuk P, Kamiński M, Włodarczyk R, Kaczmarek K, Janiszewski T, Minias P. 2016. Plumage quality mediates a life-history trade-off in a migratory bird. Frontiers in Zoology 13:47.

Prinzinger R, Misovic A. 1994. Vogelblut-eine allometrische Übersicht der Bestandteile. Journal für Ornithologie 135(2):133-165 (in German with English summary). 
406

407

408

409

410

411

412

413

414

415

416

417

418

419

420

421

422

423

424

425

426

427

428

429

430

431

432

433

434

435

436

437

Ramenofsky M. 2011. Hormones in migration and reproductive cycles of birds. In: Norris D, Lopez KH, eds. Hormones and Reproduction in Vertebrates. Academic Press, 205-236.

Ramenofsky M, Piersma T, Jukema J. 1995. Plasma corticosterone in bar-tailed godwits at a major stopover site during spring migration. Condor 97(2):580-585.

Remage-Healey L, Romero LM. 2001. Corticosterone and insulin interact to regulate glucose and triglyceride levels during stress in a bird. American Journal of Physiology 281(3):R994-R1003.

Reneerkens J, Morrison RIG, Ramenofsky M, Piersma T, Wingfield JC. 2002. Baseline and stressinduced levels of corticosterone during different life cycle substages in a shorebird on the high arctic breeding grounds. Physiological and Biochemical Zoology 75(2): 200-208.

Rohwer S, Ricklefs RE, Rohwer VG, Copple MM. 2009. Allometry of the duration of flight feather molt in birds. PLOS Biology 7:e1000132.

Roman Y, Bomsel-Demontoy MC, Levrier J, Ordonneau D, Chaste-Duvernoy D, Saint Jalme M. 2009. Influence of molt on plasma protein electrophoretic patterns in bar-headed geese (Anser indicus). Journal of Wildlife Diseases 45(3):661-671.

Romero LM, Remage-Healey L. 2000. Daily and seasonal variation in response to stress in captive starlings (Sturnus vulgaris): corticosterone. General and Comparative Endocrinology 119(1):52-59.

Thompson JE, Drobney RD. 1996. Nutritional implications of molt in male canvasbacks: variation in nutrient reserves and digestive tract morphology. Condor 98(3):512-526.

Totzke U, Fenske M, Hüppop O, Raabe H, Schach N. 1999. The influence of fasting on blood and plasma composition of herring gulls (Larus argentatus). Physiological and Biochemical Zoology 72(4):426-437.

Villegas A, Sanchez JM, Costillo E, Corbacho C. 2002. Blood chemistry and haematocrit of the black vulture (Aegypius monachus). Comparative Biochemistry and Physiology A 132(2):489-497.

Włodarczyk R, Minias P, Kaczmarek K, Janiszewski T, Kleszcz A. 2007. Different migration strategies used by two inland wader species during autumn migration, case of Wood Sandpiper Tringa glareola and Common Snipe Gallinago gallinago. Ornis Fennica 84(3):119-130.

Włodarczyk R, Kaczmarek K, Minias P, Janiszewski T. 2008. Ageing and sexing of the Common Snipe Gallinago gallinago gallinago. Wader Study Group Bulletin 115(1):45-49.

Włodarczyk R, Minias P, Gogga P, Kaczmarek K, Remisiewicz M, Janiszewski T. 2011. Sexing Common Snipe Gallinago gallinago in the field using biometrical criteria. Wader Study Group Bulletin 118(1):10-13.

Work TM. 1996. Weights, hematology, and serum chemistry of seven species of free-ranging tropical pelagic seabirds. Journal of Wildlife Diseases 32(4):643-657 
Table 1 Numbers of young common snipe in which different plasma parameters were analysed at three stages of the post-juvenile moult.

\begin{tabular}{lccc}
\hline \multirow{2}{*}{ Plasma parameter } & \multicolumn{3}{c}{ Moult stage } \\
\cline { 2 - 4 } & Before & Initial & Advanced \\
\hline Total protein & 299 & 171 & 58 \\
Triglycerides & 267 & 146 & 49 \\
Glucose & 213 & 103 & 37 \\
Albumin & 191 & 96 & 35 \\
Uric acid & 75 & 37 & 21 \\
\hline
\end{tabular}


Table 2 Total plasma protein concentration in relation to the stages of post-juvenile moult and confounding variables in young common snipe migrating through central Poland. Reduced model $R^{2}=$ $0.41\left(F_{10,517}=35.85, p<0.001\right)$. Significant predictors are marked in bold.

\begin{tabular}{lcc}
\hline Factor & $F$ & $\mathrm{p}$ \\
\hline Full model & & \\
Moult stage & $\mathbf{3 . 4 6}$ & $\mathbf{0 . 0 3 2}$ \\
Sex & 2.30 & 0.13 \\
Year & $\mathbf{7 . 4 7}$ & $<\mathbf{0 . 0 0 1}$ \\
Date & 1.51 & 0.22 \\
Hour & $\mathbf{9 . 6 8}$ & $\mathbf{0 . 0 0 2}$ \\
Reduced model & & \\
Moult stage & $\mathbf{3 . 1 3}$ & $\mathbf{0 . 0 4 5}$ \\
Sex & 2.12 & 0.15 \\
Year & $\mathbf{7 . 5 4}$ & $<\mathbf{0 . 0 0 1}$ \\
Hour & $\mathbf{9 . 1 4}$ & $\mathbf{0 . 0 0 3}$ \\
\hline
\end{tabular}


Table 3 Plasma glucose concentration in relation to the stages of post-juvenile moult and confounding variables in young common snipe migrating through central Poland. Reduced model $R^{2}=0.16\left(F_{8,344}=\right.$ 7.96, $\mathrm{p}<0.001)$. Significant predictors are marked in bold.

\begin{tabular}{lcc}
\hline Factor & $\mathrm{F}$ & $\mathrm{p}$ \\
\hline Full model & & \\
Moult stage & $\mathbf{3 . 6 0}$ & $\mathbf{0 . 0 2 8}$ \\
Sex & 0.41 & 0.52 \\
Year & 14.21 & $<\mathbf{0 . 0 0 1}$ \\
Date & $\mathbf{4 . 5 9}$ & $\mathbf{0 . 0 3 3}$ \\
Hour & 3.23 & 0.07 \\
Reduced model & & \\
Moult stage & $\mathbf{3 . 7 4}$ & $\mathbf{0 . 0 2 5}$ \\
Year & $\mathbf{1 4 . 3 5}$ & $<\mathbf{0 . 0 0 1}$ \\
Date & $\mathbf{4 . 8 2}$ & $\mathbf{0 . 0 2 9}$ \\
Hour & 3.38 & 0.07 \\
\hline
\end{tabular}


Table 4 Plasma concentrations of albumin, triglycerides, and uric acid in relation to the stages of postjuvenile moult and confounding variables in young common snipe migrating through central Poland. Significant predictors are marked in bold.

\begin{tabular}{lccccc}
\hline \multirow{2}{*}{ Factor } & \multicolumn{2}{c}{ Albumin } & \multicolumn{2}{c}{ Triglycerides } & Uric acid \\
\cline { 2 - 6 } & $\mathrm{F}$ & $\mathrm{p}$ & $\mathrm{F}$ & $\mathrm{p}$ & $\mathrm{F}$ \\
\hline Moult stage & 1.42 & 0.24 & 0.12 & 0.89 & 0.44 \\
Sex & 1.58 & 0.21 & 0.09 & 0.77 & 0.01 \\
Year & $\mathbf{9 . 0 1}$ & $<\mathbf{0 . 0 0 1}$ & $\mathbf{1 0 . 2 3}$ & $<\mathbf{0 . 0 0 1}$ & 0.30 \\
Date & 0.02 & 0.88 & 0.27 & 0.60 & $\mathbf{2 2 . 0 3}$ \\
Hour & $\mathbf{1 5 . 7 7}$ & $<\mathbf{0 . 0 0 1}$ & $\mathbf{3 . 8 7}$ & $\mathbf{0 . 0 4 9}$ & $\mathbf{2 . 5 0}$ \\
\hline
\end{tabular}


Figure 1. Map of ringing recoveries from common snipe migrating through inland Poland. Ringing sites are marked with yellow triangles, recoveries in spring or summer are marked with green dots (March September), and recoveries in autumn or winter (September - March) are marked with blues dots.

Figure adapted from Minias et al., (2010b).

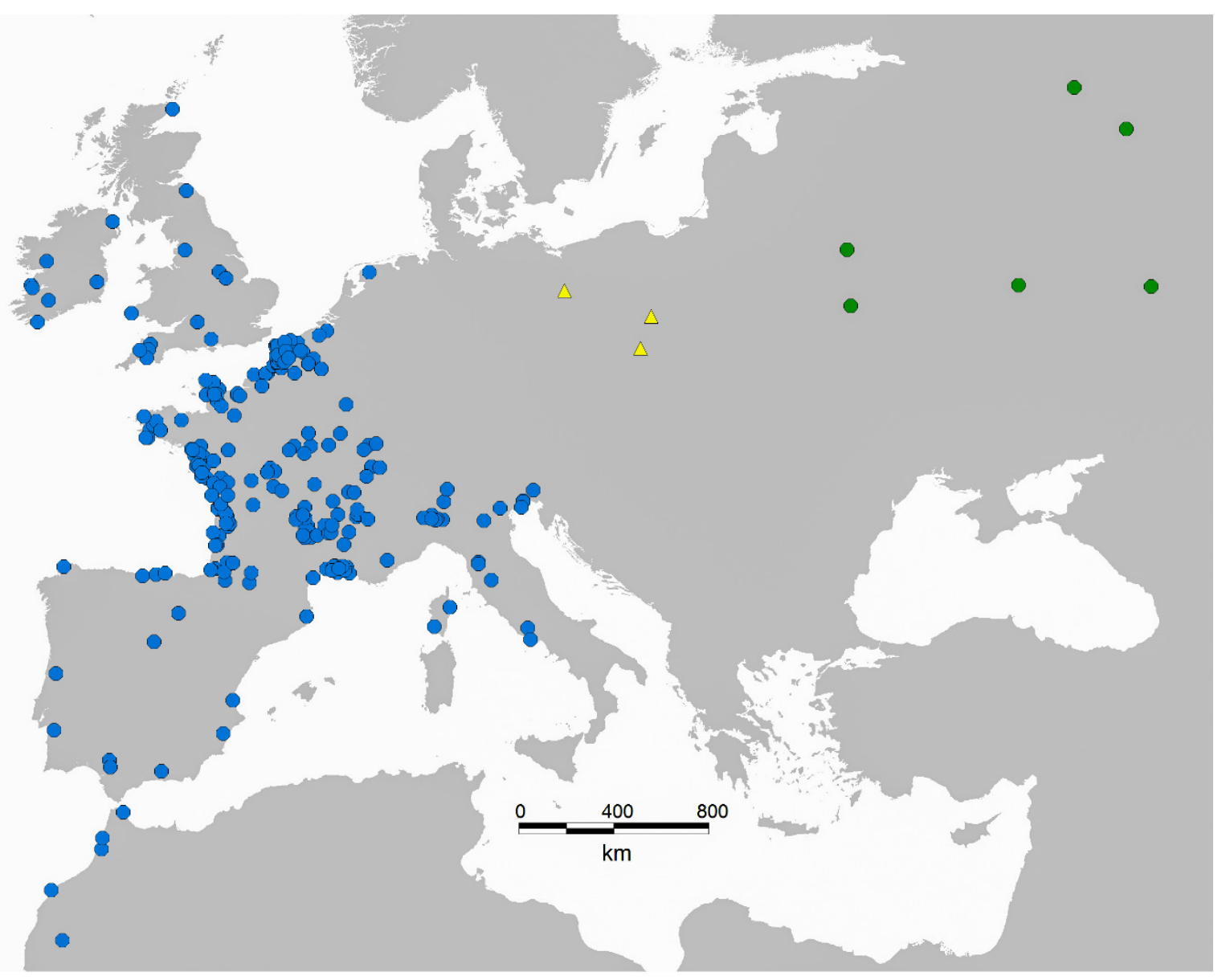


Figure 2. The extent of the post-juvenile moult in wing and tail of the common snipe. Plumage areas marked by white contours are moulted. LC - lesser wing coverts, MC - median wing coverts, TR tertials, $\mathrm{R}$ - rectrices.

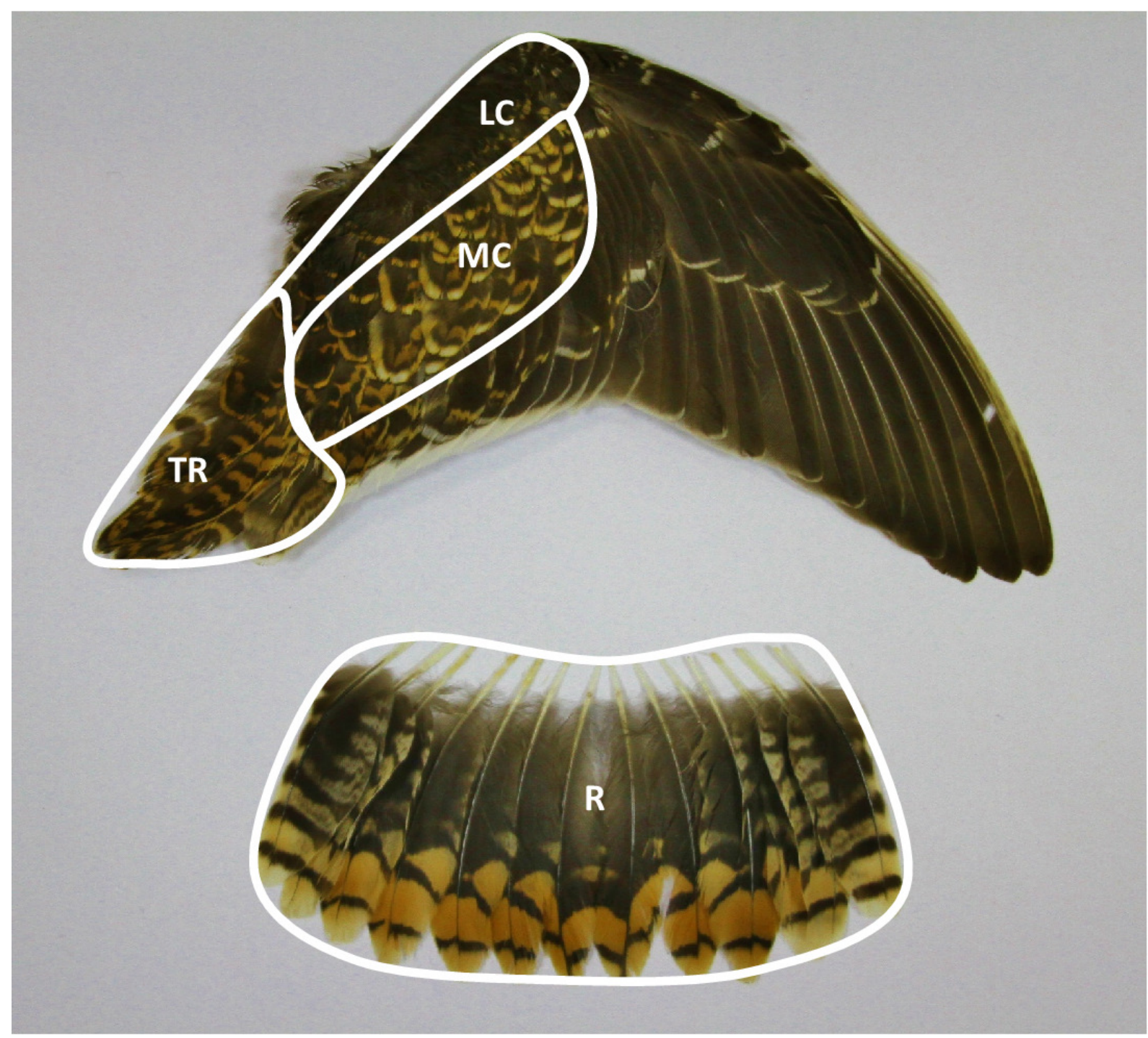


Figure 3. Changes in plasma concentrations of total protein (a) and glucose (b) between the consecutive stages of post-juvenile moult in young common snipe migrating through central Poland. Means \pm SE are presented. 


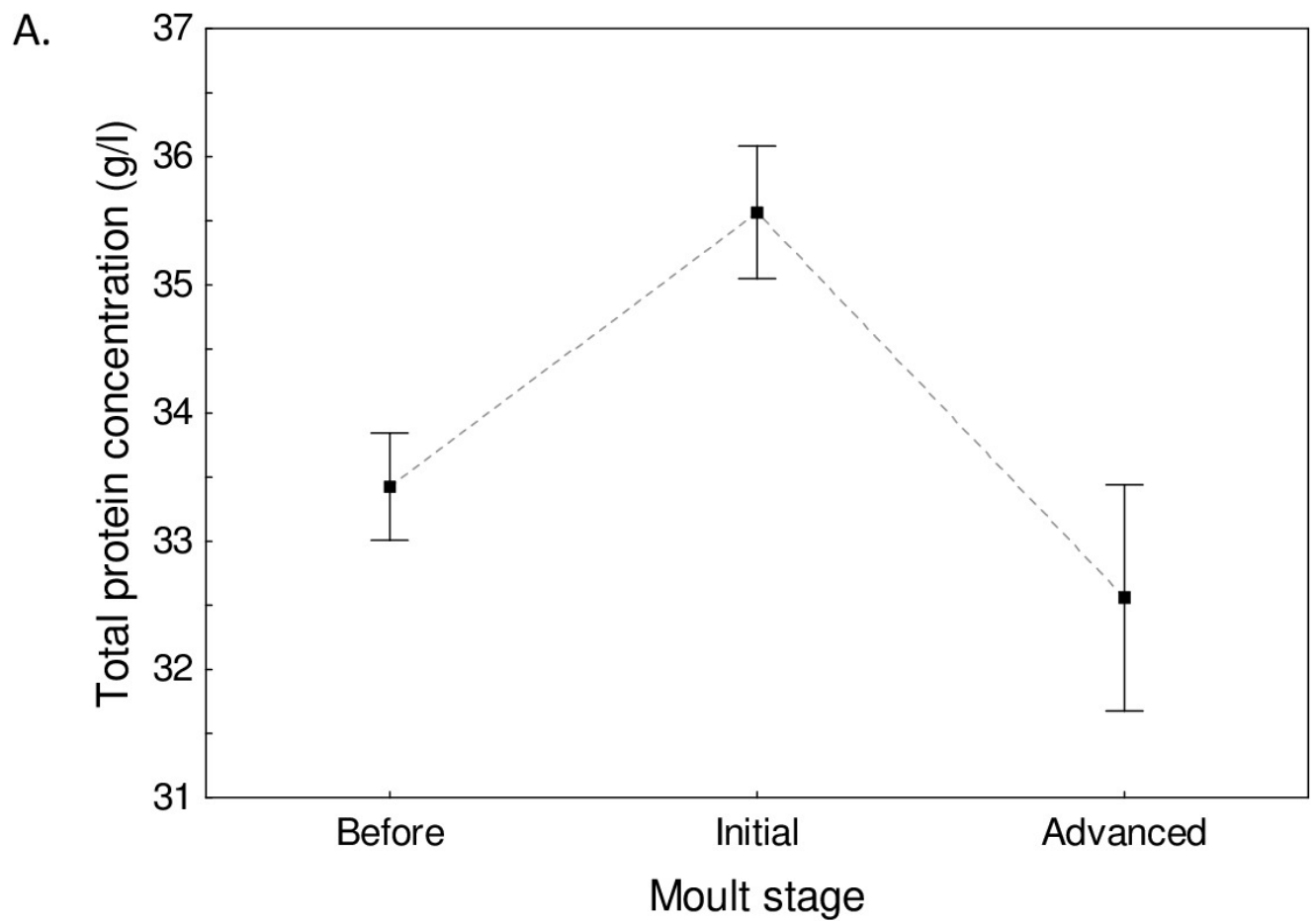

B.

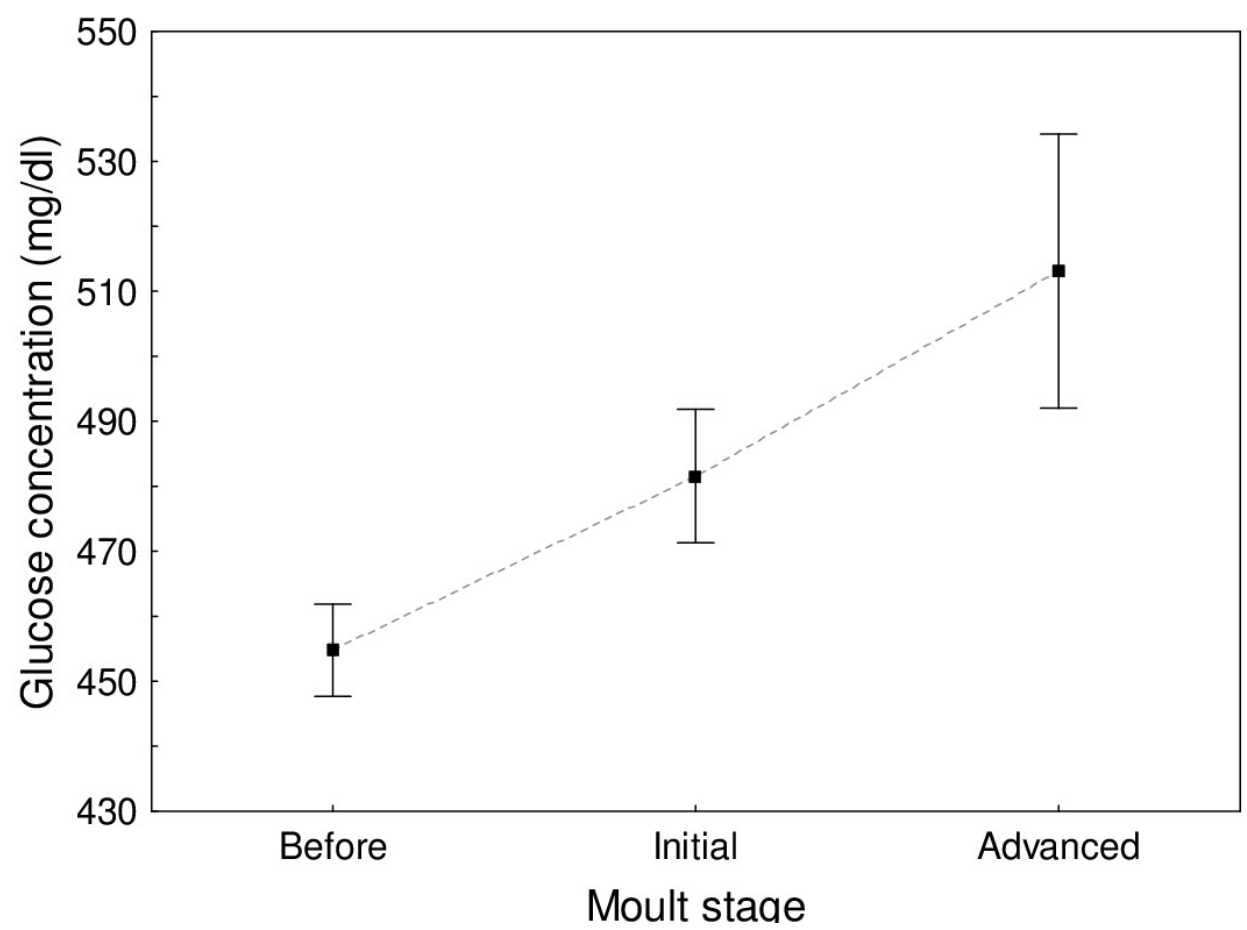


Figure 4 Changes in plasma triglyceride concentration with moult score of young common snipe in the advanced stage of post-juvenile moult. The line indicates a fitted regression $\left(y=-0.29 * x+78.13 ; R^{2}=\right.$ $0.063)$.

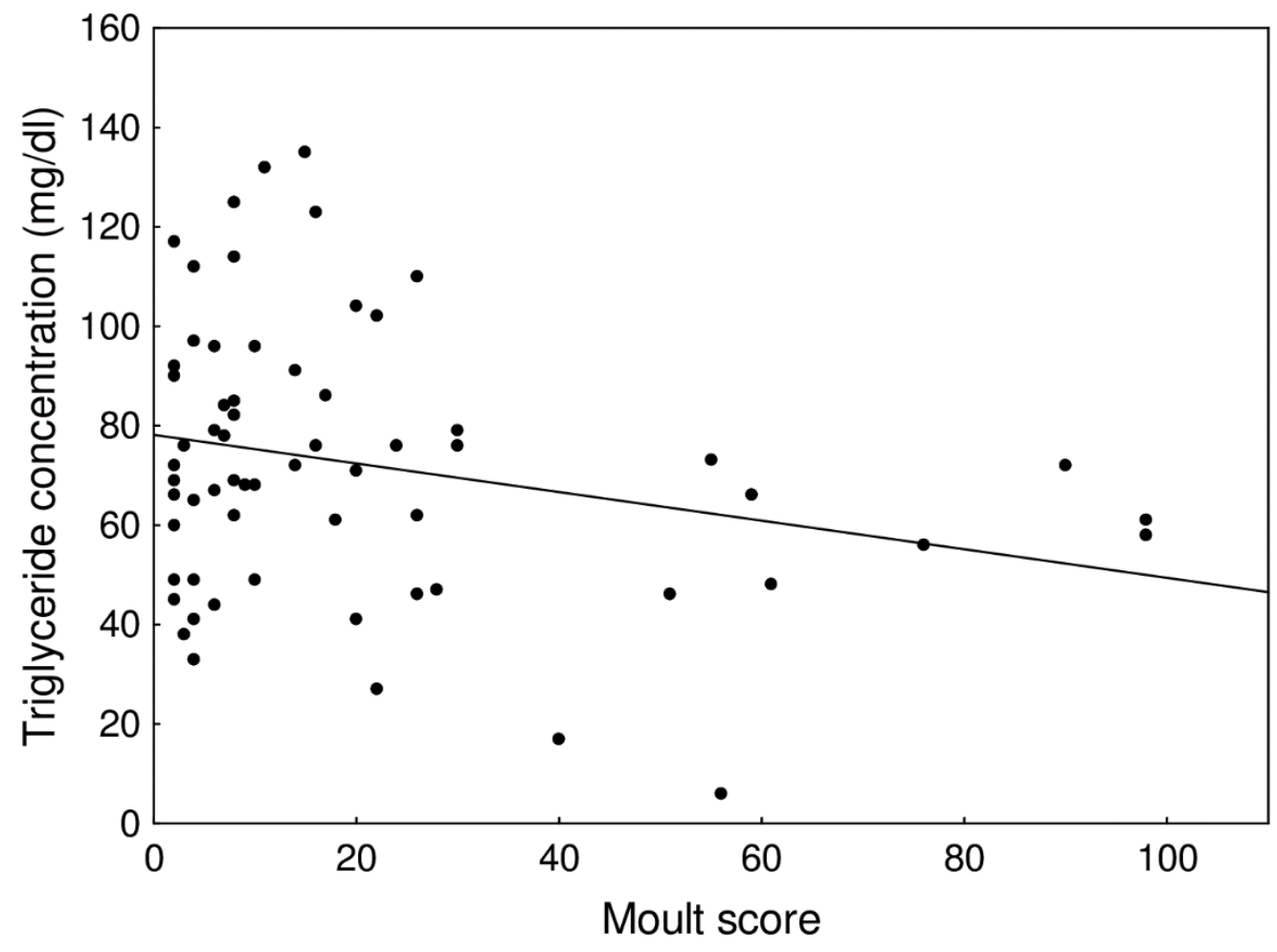

